\title{
45. ROCK AND PALEOMAGNETISM OF LEG 42A, HOLE 373A BASALTS
}

\author{
N. Petersen, Institut für Allgemeine und Angewandte Geophysik, Ludwig Maximilians Universität, \\ Munich, West Germany \\ U. Bleil, Institut für Geophysik, Ruhr Universität, Bochum, West Germany \\ and \\ P. Eisenach, Institut für Allgemeine und Angewandte Geologie, Ludwig Maximilians Universität, \\ Munich, West Germany
}

\begin{abstract}
Thirteen basalt samples have been investigated, eleven of which were oriented with respect to vertical. The natural remanent magnetization, low field susceptibility, a.c. and d.c. field stability, saturation remanence, saturation magnetization, and Curie temperature have been measured. These measurements have been complemented by ore microscopic analysis. The remanence directions of the samples closely group around the magnetic dipole field direction to be expected at the latitude of Hole $373 \mathrm{~A}$. In all samples apart from one, cation-deficient titanomagnetite is the main carrier of magnetization. It is concluded that the samples have undergone low temperature oxidation in a submarine environment.
\end{abstract}

\section{INTRODUCTION}

Thirteen basalt samples from Hole 373A have been analyzed for paleomagnetic and rock magnetic properties. The measurements have been complemented by ore microscopic observation. Eleven of the rocks were oriented with respect to vertical, two were non-oriented; only the inclination of magnetization direction can be given in absolute values.

\section{MAGNETIC MEASUREMENTS}

\section{Methods}

Remanent magnetization of the rocks was measured with a Digico spinner magnetometer. Stepwise alternating field demagnetization in $25,50,75,100,150,200$, $300,400,500$, and 1000 Oe was carried out in order to determine the "stable direction" of magnetization.

The natural remanent magnetization (NRM) of basalts normally is of a composite nature; it consists of the original thermoremanent magnetization acquired during cooling in the earth magnetic field after eruption, and also of other magnetization components acquired subsequently, like viscous magnetization and chemical magnetization. The stepwise alternating field demagnetization is suitable for removing these secondary, normally less stable components of magnetization; the more stable original thermoremanent magnetization can thus be determined.

The volume susceptibility was measured with a Bison magnetic susceptibility bridge. Isothermal saturation remanent magnetization $\left(\mathrm{J}_{\mathrm{sr}}\right)$ was produced in a $10^{4} \mathrm{Oe}$ field. The bulk coercivity $\left(\mathrm{H}_{\mathrm{c}}\right)$ and the coercivity of remanence $\left(\mathrm{H}_{\mathrm{cr}}\right)$ were determined by a progressive reduction of this remanence with d.c. magnetic fields applied in opposite direction. Curie temperature of the rocks has been determined by measuring the temperature dependence of strong field magnetization (measured in $1800 \mathrm{Oe}$ ) with a magnetic balance.

\section{Results}

The results of the magnetic measurements are summarized in Table 1. Some of the samples that were sufficiently large have been subdivided into subspecimens ( $1-\mathrm{cm}$ cubes) to test the within-sample scatter of the results. For comparison, data for other ocean-floor basalts have been included in Table 1. (It should be noted that the data of Lowrie (1974) were obtained from dredged samples and from very shallow DSDP drillholes only).

Figure 1 is a downhole plot of NRM-intensity, stable inclination, Q-factor and Curie temperature. In this figure the theoretical axial dipole field value for the inclination of the earth's magnetic field at the latitude of Hole $373 \mathrm{~A}\left(56^{\circ}\right)$ has been included for comparison as has the mean initial Curie temperature of unaltered Leg 37 basalts (Bleil and Petersen, in press). Figure 2 gives the thermomagnetic curves used in the determination of Curie temperatures.

\section{ORE MICROSCOPIC INVESTIGATION}

\section{Method}

Polished sections of all samples have been examined under the ore microscope using a Leitz Ortholux Pol microscope. To aid in the identification of the magnetic minerals magnetic colloids have also been used.

\section{Results}

With the exception of Sample 7-4, 132-135 cm, which is aphyric, all samples are slightly altered phyric 
TABLE 1

Different Magnetic Parameters of Hole 373A Basalts

\begin{tabular}{|c|c|c|c|c|c|c|c|c|c|c|c|}
\hline $\begin{array}{c}\text { Sample } \\
\text { (Interval in } \mathrm{cm} \text { ) }\end{array}$ & $\begin{array}{c}\mathrm{N} \mathrm{1} \\
\begin{array}{c}\text { Intensity } \\
\left(10^{-3}\right. \\
\text { Gauss })\end{array}\end{array}$ & 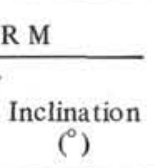 & $\begin{array}{c}\text { Stable } \\
\text { Inclinationa } \\
\left({ }^{\circ}\right)\end{array}$ & $\begin{array}{c}\text { Suscepti- } \\
\text { bilityb } \\
\left(10^{-3}\right. \\
\text { Gauss/Oe) }\end{array}$ & $Q^{c}$ & $\begin{array}{l}\text { Median } \\
\text { Destruc- } \\
\text { tive } \\
\text { Fieldd } \\
\text { (Oe) }\end{array}$ & $\begin{array}{l}\mathrm{H}_{\mathrm{c}} \\
(\mathrm{Oe})\end{array}$ & $\begin{array}{l}\mathrm{H}_{\mathrm{cr}} \\
(\mathrm{Oe})\end{array}$ & $\begin{array}{c}J_{\text {sr }} \\
\text { (Gauss) }\end{array}$ & $\begin{array}{l}\mathrm{T}_{\mathrm{c}} \\
\left({ }^{\circ} \mathrm{C}\right)\end{array}$ & $\begin{array}{c}\mathrm{I}_{20^{\circ} \mathrm{C}}^{1800 \mathrm{Oe}} \\
\left.\text { (Gauss } \mathrm{cm}^{3} / \mathrm{gr}\right)\end{array}$ \\
\hline $3-3,40-45$ & 2.44 & 55.1 & 3.9 & 0.37 & 15 & 63 & - & - & - & 287 & 0.15 \\
\hline 2 & 0.90 & 13.1 & -8.3 & 0.24 & 8 & 161 & - & - & - & - & - \\
\hline Sample mean & 1.67 & 34.1 & -2.2 & 0.31 & 11 & 112 & - & - & - & - & - \\
\hline $6, \mathrm{CC}$ & 1.68 & - & - & 0.48 & 8 & 126 & - & - & - & 270 & 0.28 \\
\hline $7-1,108-110 \quad 1$ & 8.48 & 62.3 & 58.1 & 1.60 & 12 & 91 & 87 & 146 & 0.40 & 510 & 0.96 \\
\hline - & 6.25 & 62.3 & 58.1 & 1.74 & 8 & 106 & 90 & 152 & 0.40 & - & - \\
\hline Sample mean & 7.37 & 62.3 & 58.1 & 1.67 & 10 & 99 & 89 & 149 & 0.40 & - & - \\
\hline $7-2,51-54$ & 3.28 & 64.4 & 61.3 & 0.35 & 21 & 124 & - & - & - & 295 & 0.34 \\
\hline $7-2,100-106 \quad 1$ & 2.43 & 41.0 & 51.7 & 0.57 & 10 & 78 & 78 & 124 & 0.13 & - & - \\
\hline 2 & 1.26 & 50.9 & 52.5 & 0.40 & 7 & 83 & 96 & 135 & 1.19 & - & - \\
\hline 3 & 1.01 & 58.7 & 46.4 & 0.31 & 7 & 120 & 121 & 177 & 1.22 & - & - \\
\hline Sample mean & 1.57 & 50.2 & 50.2 & 0.43 & 8 & 94 & 98 & 145 & 0.85 & - & - \\
\hline $7-2,143-146$ & 3.54 & 61.3 & 65.4 & 0.35 & 22 & 128 & - & - & - & - & - \\
\hline $7-3,55-57$ & 3.84 & 73.4 & 56.6 & 0.29 & 29 & 169 & - & - & - & - & - \\
\hline $7-3,105-110 \quad 1$ & 1.61 & 69.0 & 62.4 & 0.37 & 10 & 127 & 147 & 208 & 0.25 & 285 & 0.28 \\
\hline 2 & 1.26 & 61.4 & 57.0 & 0.34 & 8 & 142 & 145 & 216 & 0.25 & - & - \\
\hline 3 & 1.53 & 59.6 & 53.5 & 0.40 & 9 & 122 & 145 & 220 & 0.27 & - & - \\
\hline Sample mean & 1.47 & 63.3 & 57.6 & 0.37 & 9 & 130 & 146 & 215 & 0.26 & - & - \\
\hline $7-4,3-5$ & 1.76 & 55.8 & 58.8 & 0.33 & 12 & 135 & - & - & - & - & - \\
\hline $7-4,132-135$ & 1.31 & 75.9 & 62.3 & 0.50 & 6 & 94 & 62 & 120 & 0.14 & 270 & 0.43 \\
\hline $11-1,83-85$ & 5.95 & 39.0 & 31.4 & 1.30 & 10 & 99 & 55 & 98 & 0.24 & - & - \\
\hline $11-1,137-139$ & 7.11 & 51.9 & 43.6 & 1.43 & 11 & 60 & 48 & 91 & 0.22 & 295 & 0.66 \\
\hline 12 , outer barrel 1 & 3.53 & - & - & 1.99 & 4 & 59 & 38 & 80 & 0.22 & 215 & 0.73 \\
\hline 2 & 1.53 & - & - & 2.38 & 1 & 38 & 42 & 82 & 0.23 & - & - \\
\hline 3 & 2.42 & - & - & 2.17 & 3 & 24 & 42 & 83 & 0.19 & - & - \\
\hline Sample mean & 2.49 & - & - & 2.18 & 3 & 40 & 41 & 82 & 0.22 & - & - \\
\hline Mean Values & & & & & & & & & & & \\
\hline All 373 A & 3.31 & 57.4 & 49.4 & 0.77 & 12 & 109 & 77 & 129 & 0.33 & 274 & 0.48 \\
\hline samples & \pm 2.18 & \pm 13.0 & \pm 19.7 & \pm 0.64 & \pm 7 & \pm 33 & \pm 37 & \pm 46 & \pm 0.24 & \pm 28 & \pm 0.27 \\
\hline $\begin{array}{l}\text { DSDP-basalts } \\
\text { (Lowrie, } \\
\text { 1974) }\end{array}$ & $\begin{array}{r}5.08 \\
\pm 4.38\end{array}$ & - & - & $\begin{array}{r}2.61 \\
\pm 2.48\end{array}$ & - & $\begin{array}{r}74 \\
\pm 38\end{array}$ & - & - & - & - & - \\
\hline $\begin{array}{l}\text { Leg } 34 \text { basalts } \\
\text { (Ade-Hall } \\
\text { et.al., 1976) }\end{array}$ & $\begin{array}{r}6.11 \\
\pm 6.94\end{array}$ & - & - & $\begin{array}{r}3.07 \\
\pm 3.38\end{array}$ & $\begin{array}{r}15 \\
\pm 15\end{array}$ & $\begin{array}{r}177 \\
\pm 194\end{array}$ & - & - & - & $\begin{array}{l}253 \\
\pm 94\end{array}$ & $\begin{array}{r}1.38 \\
\pm 1.20\end{array}$ \\
\hline $\begin{array}{l}\text { Leg } 37 \text { basalts } \\
\text { (Bleil and } \\
\text { Petersen, } \\
1976 \text { ) }\end{array}$ & $\begin{array}{r}3.16 \\
\pm 3.13\end{array}$ & - & - & $\begin{array}{r}0.34 \\
\pm 0.29\end{array}$ & $\begin{array}{r}26 \\
\pm 29\end{array}$ & $\begin{array}{r}328 \\
\pm 157\end{array}$ & - & - & $\begin{array}{r}0.32 \\
\pm 0.11\end{array}$ & $\begin{array}{l}287 \\
\pm 71\end{array}$ & $\begin{array}{r}0.28 \\
\pm 0.20\end{array}$ \\
\hline
\end{tabular}

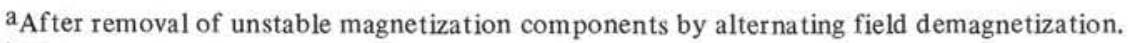

bVolume susceptibility - low field susceptibility.

cKoenigsberger Q Factor.

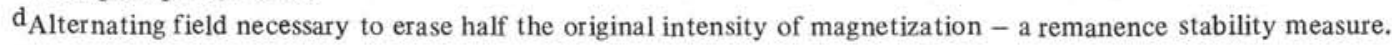

basalt containing feldspar phenocrysts and broken plagioclase laths. Large variations in the pyroxene and, particularly, olivine content exist. The most abundant ore phase in the rocks is skeletal titanium-rich titanomagnetite showing varying degree of maghemitization. Sample 7-1, 108-110 cm, is the only specimen where the grains of titanomagnetite consist of intergrowths of lamellae of secondary ilmenite with titanium-poor titanomagnetite, which indicate that high temperature deuteric oxidation has taken place (Figure $3[\mathrm{~B}]$ ). In all the other samples many titanomagnetite grains contain patterns of curved and branching cracks (Figure 3[A]), similar to those described by Ade-Hall et al. (1976a). These cracks are probably due to low-temperature oxidation (maghemitization) and associated volume change. The cracks are often subsequently filled with sulfide.

A large number of discrete grains of primary ilmenite, sometimes mantled by titanomagnetite, is present in all samples. The sulfides, also present in all samples, though to a much smaller amount than the $\mathrm{Fe}-\mathrm{Ti}$ oxides, predominantly consist of grains of pyrrhotite and chalcopyrite (the latter intergrown with bornite) and to a minor degree of intergrowths of pyrite and marcasite. In general the petrography of the opaque minerals strongly resembles that of the Leg 34 ocean floor basalts of the Nazca Plate as described by AdeHall et al. (1976a). Tables 2 and 3 give a brief description of the opaque mineralogy of the individual samples. 


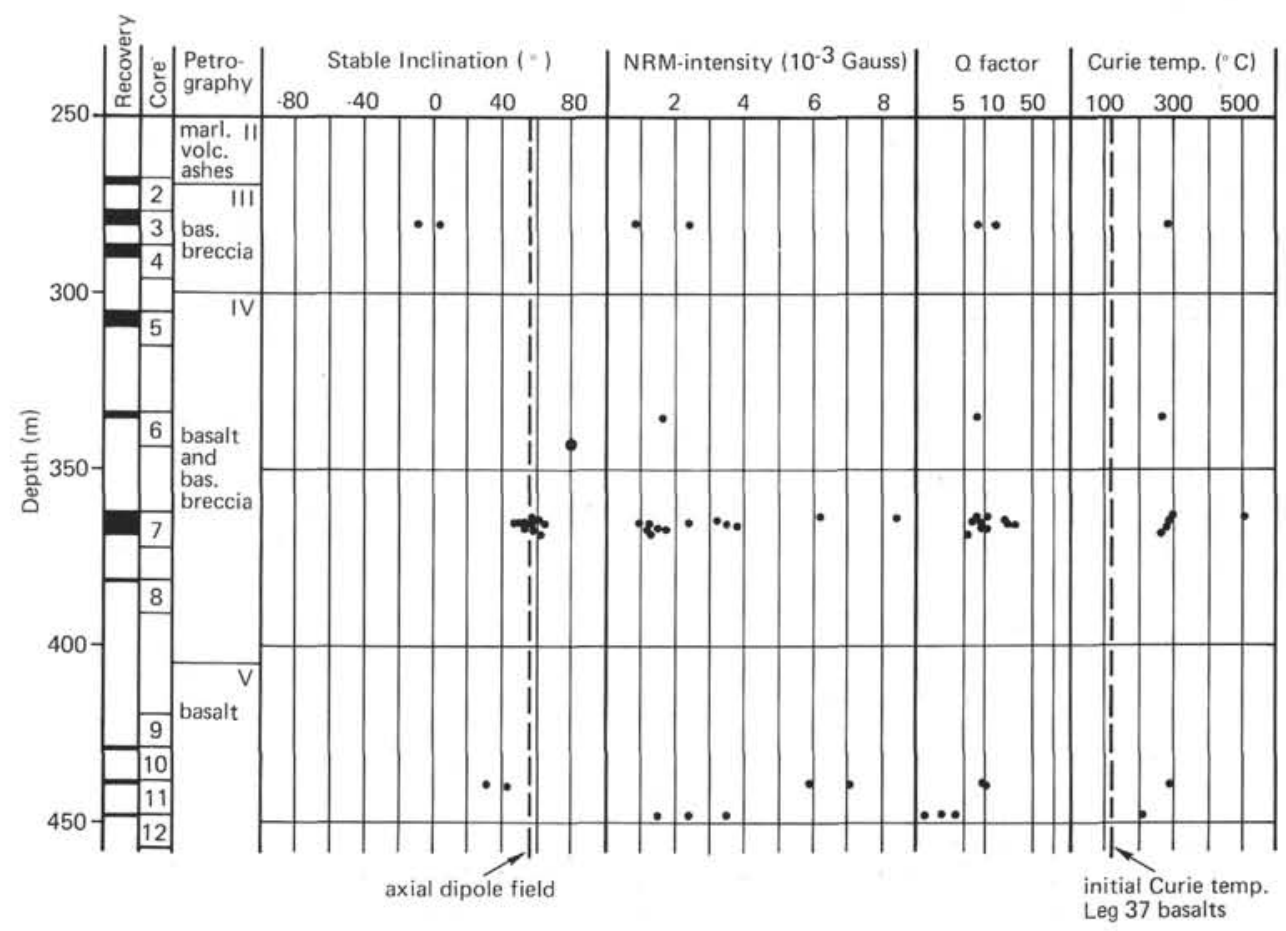

Figure 1. Down hole plot of different magnetic parameters for Hole $373 \mathrm{~A}$ basalts. The inclination of the earth's magnetic axial dipole field at the latitude of Hole $373 \mathrm{~A}$ has been given as a reference value. The mean value of the initial Curie temperatures for DSDP Leg 37 basalts (Bleil and Petersen, 1976) prior to any subsequent alteration of the magnetic mineral phase is also indicated.

\section{DISCUSSION AND SUMMARY}

Titanomagnetite is the dominant opaque phase in all investigated samples, with ilmenite less and sulfides much less abundant. The skeletal shape of the titanomagnetites (Figure 3[A]) is indication of rapid cooling of the basaltmagma. The carrier of the remanent magnetization are the grains of titanomagnetite. There may also be a negligible contribution from the sulfides (pyrrhotite). With one exception all samples show features of maghemitization of the titanomagnetites which is due to low temperature oxidation (below $250^{\circ} \mathrm{C}$ ) and typical of deep ocean weathering (halmyrolysis) as it has been observed in ocean-floor basalts from, for example, Leg 34 (Ade-Hall et al., 1976a) and Leg 37 (Bleil and Petersen, in press). The frequent occurrence of irregular patterns of cracks in the titanomagnetite grains is probably an indication of volume change associated with low temperature oxidation.

The exception is sample 7-1, 108-110 cm, where the titanomagnetite grains consist of intergrowths of secondary ilmenite lamellae with titanium-poor titanomagnetite indicating deuteric high temperature oxidation. The high Curie temperature of $510^{\circ} \mathrm{C}$ of the sample is in good agreement with the ore microscopic observation of high-temperature oxidation. In constrast to subaerial basalts, high-temperature oxidation of titanomagnetites seems to be rare in ocean-floor basalts and may occur only in the center of massive flows (Watkins and Haggerty, 1967; Grommé et al., 1969).
All other samples, showing the features of lowtemperature oxidation, have lower Curie temperatures with a mean of $274^{\circ} \mathrm{C}$. This value is distinctly higher than the average Curie temperature of unaltered basalts with stoichiometric titanomagnetites. The mean "unaltered" Curie temperature of the Leg 34 basalts, for example, is $140^{\circ} \mathrm{C}$ (Ade-Hall et al., 1976); of the Leg 37 basalts it is $119^{\circ} \mathrm{C}$ (Bleil and Petersen, in press). Another value of mean "unaltered" Curie temperature obtained from 269 analyses of a great variety of continental basalts is $168^{\circ} \mathrm{C}$ (Petersen, 1976). The difference between these low Curie temperatures and the elevated mean Curie temperature of $274^{\circ} \mathrm{C}$ of the samples investigated here can most reasonably be explained by the microscopically observed maghemitization of the titanomagnetites, as the Curie temperature of titanomagnetite increases with the degree of maghemitization (Readman and O'Reilly, 1972). In other words the elevated Curie temperatures support the microscopic observation of maghemitization of the titanomagnetites.

The remanence directions of the samples group closely around the magnetic dipole field direction to be expected at the latitude of Site 373A. The exception is sample $3-3,40-45 \mathrm{~cm}$, which has a very shallow inclination and is from a different lithological unit than the deeper samples. Sample 7-1, 108-110 cm, being unusual because of the high temperature oxidation features, falls well into this group (see Figure 1) which very likely means that it also had been formed under 

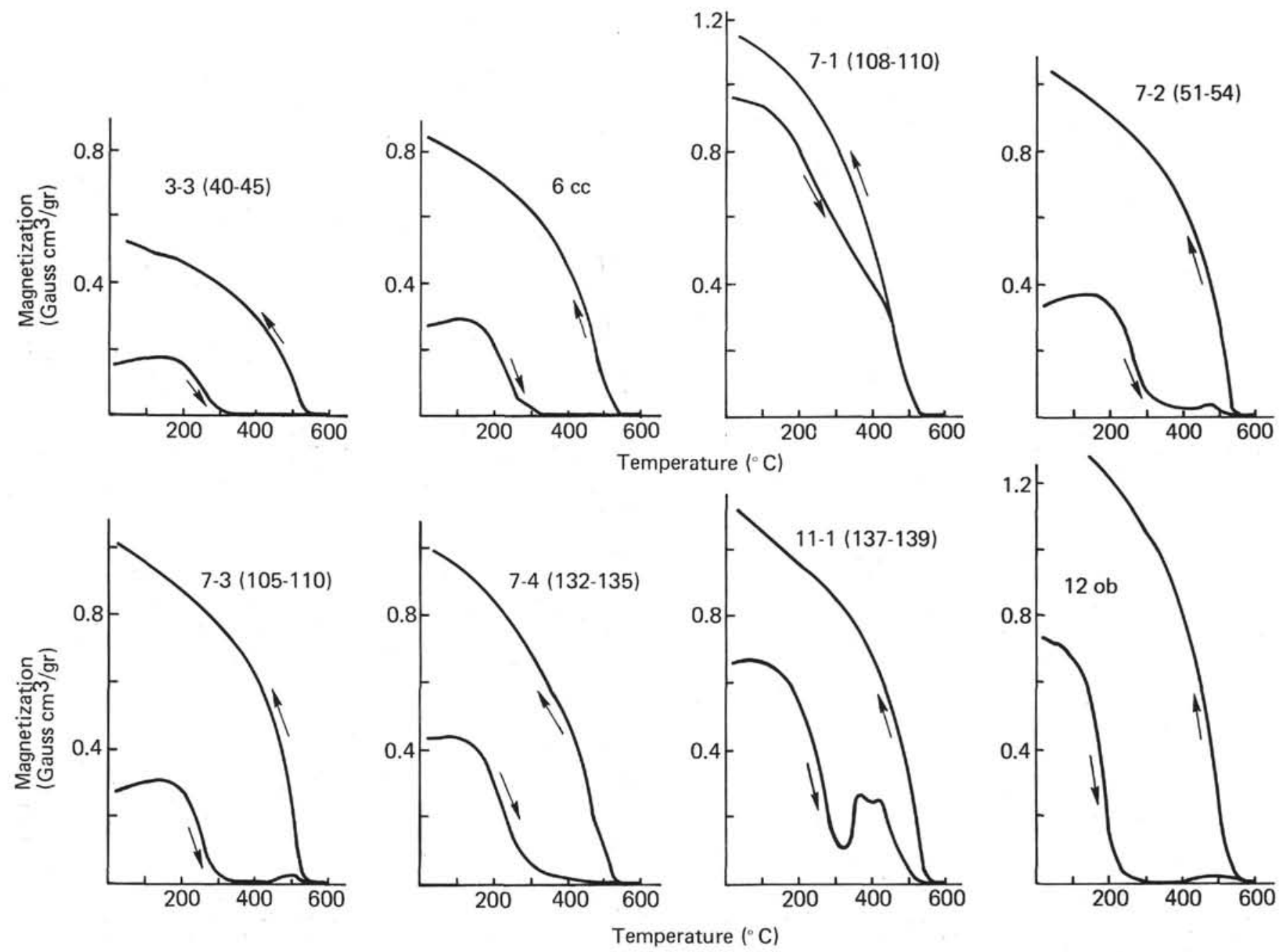

Figure 2. Strong field magnetization (measured in a magnetic field of 1800 Oe) versus temperature for Hole $373 \mathrm{~A}$ basalts.

The distinct irreversibility of heating and cooling curves is indicative of titanomaghemite as carrier of magnetization.

the same conditions as the other samples, namely the submarine environment.

\section{ACKNOWLEDGMENTS}

This study is a combined contribution of the Institut für Allgemeine und Angewandte Geophysik, of the Institut für Allgemeine und Angewandte Geologie, both Ludwig-Maximilians Universität, Munich, and of the Institut für Geophysik, Ruhr-Universität, Bochum. We thank Prof. Dr. G. Angenheister, Prof. Dr. D. Klemm, and Prof. Dr. H. Baule for generously making available the facilities of the above named institutions and for their support throughout the study. We are grateful to the members of the shipboard party Prof. Dr. K. Hsü and Dr. F. Fabricius who provided the samples for this investigation. The paper was also reviewed by Dr. F. Fabricius and by Prof. G. Angenheister, Munich.

Financial support of the Deutsche Forschungsgemeinschaft is gratefully acknowledged.

\section{REFERENCES}

Ade-Hall, J. M. and Johnson, H. P., 1976. Paleomagnetism of basalts, Leg 34. Initial Reports of the Deep Sea Drilling Project, Volume 34: Washington (U.S. Government Printing Office), p. 513-532.
Ade-Hall, J. M., Fink, L. K., and Johnson, H. P., 1976a. Petrography of opaque minerals, Leg 34. Initial Reports of the Deep Sea Drilling Project, Volume 34: Washington (U.S. Government Printing Office), p. 349-362.

Ade-Hall, J. M., Johnson, H. P., and Ryall, P. J. C., 1976b. Rockmagnetism of basalt, Leg 34. Initial Reports of the Deep Sea Drilling Project, Volume 34: Washington (U.S. Government Printing Office), p. 459-468.

Bleil, U. and Petersen, N., in press. Magnetic properties of basement rocks, Leg 37, Site 332. Initial Reports of the Deep Sea Drilling Project, Volume 37: Washington (U.S. Government Printing Office).

Grommé, C. S., Wright, T. L., and Peck, D. L., 1969. Magnetic properties and oxidation of iron-titanium oxide minerals in Alae and Makaopuhi lava lakes, Hawaii: J. Geophys. Res., v. 74, p. 5277-5293.

Lowrie, W., 1974. Oceanic basalt magnetic properties and the Vine and Matthews hypothesis: J. Geophys., v. 40, p. 513-536.

Petersen, N., 1976. Notes on the variation of magnetization within basalt lava flows and dikes: Pageoph, v. 114, p. 177-193.

Readman, P. W. and O'Reilly, W., 1972. Magnetic properties of oxidized (cation-deficient) titanomagnetites $(\mathrm{Fe}$, $\mathrm{Ti}, \square)_{3} \mathrm{O}_{4}$ : J. Geomag. Geoel., v. 24 , p. 69-90.

Watkins, N. D. and Haggerty, S. E., 1967. Primary oxidation variation and petrogenesis in a single lava: Contr. Min. Petr., v. 15, p. 251-271. 

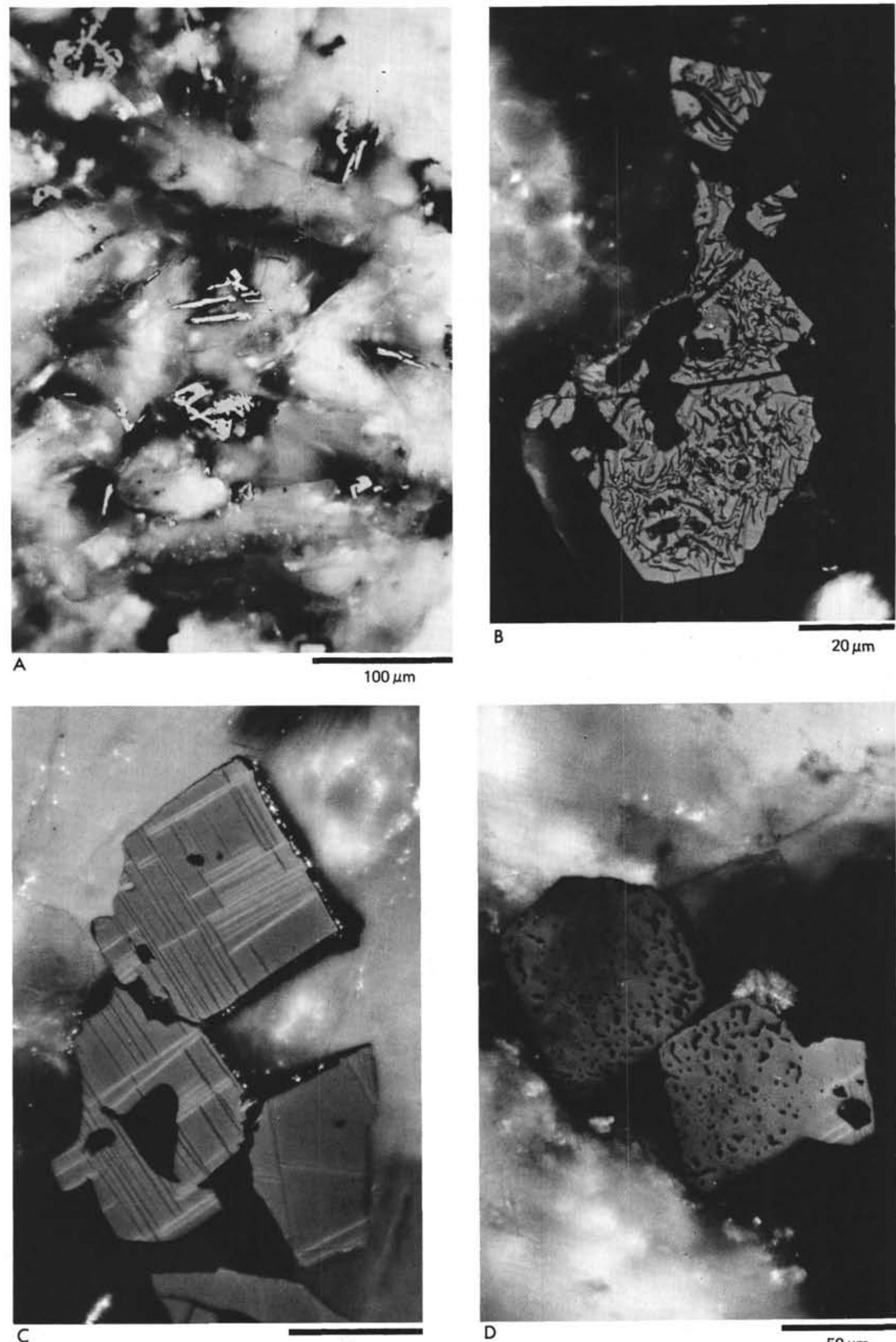

$50 \mu \mathrm{m}$

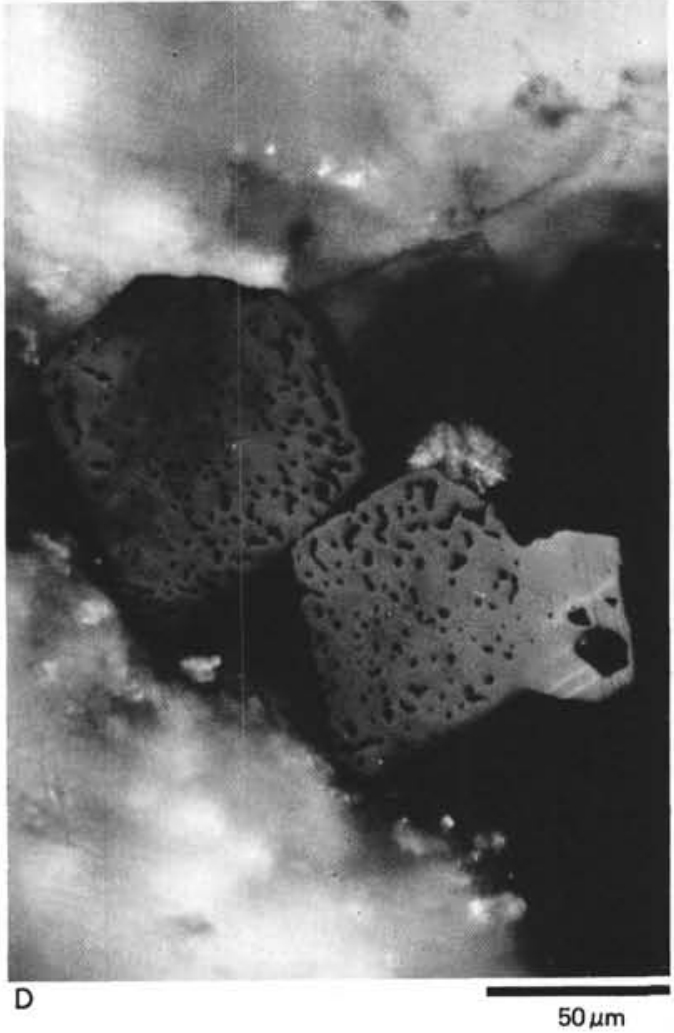

Figure 3. (A) Skeletal titanomagnetite (white) and laths of ilmenite (white, center of the picture). Sample 373A-6, CC; (B) Skeletal titanomagnetite (light grey) with volume change cracks, partly filled by a red brown mineral (ilmenite?). Sample 373A-7-2, 100-106 cm; (C) Subhedral to anhedral titanomagnetite (grey) with exsolution lamellae of ilmenite (light grey and dark grey). Partly crossed nicols. Sample $373 \mathrm{~A}-7-1,108-110 \mathrm{~cm}$; (D) Euhedral, porous grains of chrome-aluminum spinel (dark grey). Titanomagnetite with ilmenite exsolution lamellae at the rim (light grey). Sample 373A-7-1, 108-110 cm. 
TABLE 2

Ore Microscopic Description of the Hole 373A Basalts

\begin{tabular}{|c|c|c|c|c|c|}
\hline \multirow{2}{*}{$\begin{array}{c}\text { Sample } \\
\text { (Interval in cm) }\end{array}$} & \multirow[b]{2}{*}{ General Petrography } & \multirow[b]{2}{*}{ Titanomagnetite } & \multicolumn{2}{|c|}{ Ore Phases } & \multirow[b]{2}{*}{ Other Phases } \\
\hline & & & Ilmenite & Sulfides & \\
\hline $3-3,40-45$ & $\begin{array}{l}\text { Phyric basalt with tra- } \\
\text { chytic texture. Large } \\
\text { euhedral glomerocrysts of } \\
\text { alkali feldspar, in a } \\
\text { groundmass of smaller } \\
\text { plag.-laths. Pyroxene and } \\
\text { chlorite between the } \\
\text { laths. Few olivine grains. }\end{array}$ & $\begin{array}{l}\text { Skeletal, mostly lying } \\
\text { between the laths. } \\
\text { Most of the grains have a } \\
\text { Ti-rich core and a broad } \\
\text { rim of maghemite. }\end{array}$ & $\begin{array}{l}\text { Small, long laths, } \\
\text { scattered over the } \\
\text { groundmass. Of- } \\
\text { ten mantled by } \mathrm{Ti} \text {. } \\
\text { mag. }\end{array}$ & $\begin{array}{l}\text { Few small roundish } \\
\text { grains, consisting of } \\
\text { an intergrowth of } \\
\text { marcasite with } \\
\text { limonite. }\end{array}$ & $\begin{array}{l}\text { Limonite often forms the } \\
\text { seam of decomposed oli- } \\
\text { vine, of ten replaces ti.mag. } \\
\text { Chrome-aluminum spinel, } \\
\text { sometimes zoned with rim } \\
\text { of magnetite, sometimes } \\
\text { porous with tiny spots of } \\
\text { mag. }\end{array}$ \\
\hline $6, \mathrm{CC}$ & $\begin{array}{l}\text { Phyric, amygdaloidal ba- } \\
\text { salt with ophitic texture. } \\
\text { Compared to Section 3-3 } \\
\text { less Pl-phenocrysts, but } \\
\text { more Cl. }\end{array}$ & $\begin{array}{l}\text { Skeletal to anhedral } \\
\text { grains. Maghemitization } \\
\text { similar as in Section 3-3. }\end{array}$ & $\begin{array}{l}\text { Similar to Section } \\
3-3 \text {. }\end{array}$ & $\begin{array}{l}\text { Similar to Section } \\
3-3 \text {. }\end{array}$ & $\begin{array}{l}\text { Vesicles and veinlets in and } \\
\text { around the } 01 \text { lined by } \\
\text { limonite. }\end{array}$ \\
\hline $7-1,108-110$ & $\begin{array}{l}\text { Phyric, coarser grained } \\
\text { basalt. Compared to Sec- } \\
\text { tion 3-3 more and larger } \\
\text { euhedral to subhedral } 01 \text {. }\end{array}$ & $\begin{array}{l}\text { Large skeletal grains with } \\
\text { ilmenite exsolution paral- } \\
\text { lel }(100) \text { and }(010) \text {. } \\
\text { Deuteric high tempera- } \\
\text { ture oxidation. }\end{array}$ & $\begin{array}{l}\text { Similar to Section } \\
3-3 \text {. }\end{array}$ & $\begin{array}{l}\text { Few small pyrrhotite } \\
\text { inclusions in Ti, mag. }\end{array}$ & $\begin{array}{l}\text { Limonite and chrome- } \\
\text { aluminum spinel similar to } \\
\text { Section 3-3. }\end{array}$ \\
\hline $7-2,51-54$ & $\begin{array}{l}\text { Similar to Section } 7-1 \text {, } \\
\text { but more and larger } \\
\text { feldspar glomerocrysts. }\end{array}$ & Like $6, \mathrm{CC}$ & Like Section 3-3. & Like Section 3-3. & $\begin{array}{l}\text { Limonite similar to Section } \\
3-3 \text {. }\end{array}$ \\
\hline $7-2,100-106$ & $\begin{array}{l}\text { Phyric basalt, less coarse } \\
\text { grained than Section } 7-1 \text {. }\end{array}$ & $\begin{array}{l}\text { Skeletal to anhedral with } \\
\text { volume change cracks, } \\
\text { partly filled by a red- } \\
\text { brown mineral } \\
\text { (ilmenite?). }\end{array}$ & $\begin{array}{l}\text { Similar to Section } \\
3-3 \text {. }\end{array}$ & $\begin{array}{l}\text { Small grains of chal- } \\
\text { copyrite with inter- } \\
\text { growths of bornite. }\end{array}$ & $\begin{array}{l}\text { Limonite similar to Section } \\
3-3 \text {. }\end{array}$ \\
\hline $7-2,143-146$ & Phyric basalt & $\begin{array}{l}\text { Skeletal, with volume } \\
\text { change cracks, of ten } \\
\text { lined by tiny hematite } \\
\text { crystals. }\end{array}$ & $\begin{array}{l}\text { Similar to Section } \\
3-3 \text {. }\end{array}$ & Only traces. & $\begin{array}{l}\text { Limonite similar to Section } \\
\text { 3-3. Chrome-aluminum } \\
\text { spinel with vaguely devel- } \\
\text { oped rims of magnetite. }\end{array}$ \\
\hline $7-3,55-57$ & Phyric basalt & $\begin{array}{l}\text { Like Sample 7-2, } 143- \\
146 .\end{array}$ & $\begin{array}{l}\text { Similar to Section } \\
3-3 \text {. }\end{array}$ & Only traces. & $\begin{array}{l}\text { Limonite and chrome- } \\
\text { aluminum spinel similar to } \\
\text { Section } 3-3 \text {. }\end{array}$ \\
\hline $7-3,105-110$ & $\begin{array}{l}\text { Phyric basalt, increasing } \\
\text { content of large feldspar } \\
\text { glomerocrysts. }\end{array}$ & $\begin{array}{l}\text { Like Sample 7-2, 143- } \\
146 .\end{array}$ & $\begin{array}{l}\text { Similar to Section } \\
3-3 \text {. }\end{array}$ & $\begin{array}{l}\text { Tiny grains lined up } \\
\text { to garlands. }\end{array}$ & Similar to Section 3-3. \\
\hline $7-4,3-5$ & $\begin{array}{l}\text { Phyric basalt, very little } \\
\text { olivine only. }\end{array}$ & $\begin{array}{l}\text { Like Sample 7-2, 143- } \\
146 .\end{array}$ & $\begin{array}{l}\text { Similar to Section } \\
3-3 \text {. }\end{array}$ & $\begin{array}{l}\text { Tiny grains lined up } \\
\text { to garlands. }\end{array}$ & Similar to Section 3-3. \\
\hline $7-4,132-135$ & $\begin{array}{l}\text { Aphyric, amygdaloidal } \\
\text { basalt, vesicles filled with } \\
\text { white calcite. }\end{array}$ & $\begin{array}{l}\text { Very fine, skeletal, mag- } \\
\text { hemitization similar as in } \\
\text { Sample } 7-2,143-146 \text {. }\end{array}$ & Like Section 3-3. & Like Section 3-3. & No record \\
\hline $11-1,83-85$ & Aphyric basalt & $\begin{array}{l}\text { Skeletal with volume } \\
\text { change cracks, which are } \\
\text { filled by tiny hematite } \\
\text { and spinel crystals. }\end{array}$ & Like Section 3-3. & Like Section 3-3. & No record \\
\hline $11-1,137-139$ & Phyric basalt & $\begin{array}{l}\text { Skeletal, partly inter- } \\
\text { grown with sulfide. Vol- } \\
\text { ume change cracks filled } \\
\text { by sulfide. }\end{array}$ & $\begin{array}{l}\text { Similar to Section } \\
3-3 \text {. }\end{array}$ & $\begin{array}{l}\text { Mostly intergrown } \\
\text { with ti.-mag. }\end{array}$ & No record \\
\hline 12 , outer barrel & $\begin{array}{l}\text { Phyric, coarser grained } \\
\text { basalt with ophitic } \\
\text { texture. }\end{array}$ & $\begin{array}{l}\text { Like Sample } 11-1,137 \text { - } \\
139 .\end{array}$ & $\begin{array}{l}\text { Like Sample 11-1, } \\
137-139 .\end{array}$ & $\begin{array}{l}\text { Like Sample 11-1, } \\
137-139 .\end{array}$ & No record \\
\hline
\end{tabular}

TABLE 3

Mean Grain Diameter in Microns of the Different Ore Phases in the Hole 373A Basalts

\begin{tabular}{lccccc}
\hline $\begin{array}{c}\text { Sample } \\
\text { Interval in cm) }\end{array}$ & $\begin{array}{c}\text { Titano- } \\
\text { magnetite }\end{array}$ & Ilmenite & Sulfide & Limonite & Chromite \\
\hline $3-3,40-45$ & 18 & 15 & 6 & 86 & - \\
6, CC & 19 & 16 & 7 & 35 & - \\
$7-1,108-110$ & 54 & 18 & 5 & 36 & 10 \\
$7-2,51-54$ & 43 & 30 & 6 & 47 & - \\
$7-2,100-106$ & 33 & 26 & 20 & 32 & - \\
$7-2,143-146$ & 22 & 20 & $\operatorname{tr}$ & 26 & 144 \\
$7-3,55-57$ & 36 & 20 & $\operatorname{tr}$ & 12 & - \\
$7-3,105-110$ & 26 & 18 & 21 & - & 31 \\
$7-4,3-5$ & 27 & 18 & 6 & 77 & - \\
$7-4,132-135$ & 9 & 11 & 10 & - & - \\
$11-1,83-85$ & 12 & 15 & 10 & - & - \\
$11-1,137-139$ & 14 & 15 & 13 & - & - \\
12, outer barrel & 26 & 29 & 10 & - & \\
\hline
\end{tabular}

